\title{
Production of fish larvae and their prey in subarctic southeastern Hudson Bay*
}

\author{
R. Drolet, L. Fortier, D. Ponton, M. Gilbert \\ Département de biologie, Université Laval, Ste-Foy, Québec, Canada G1K 7 P4
}

\begin{abstract}
In the ice-covered southeastern Hudson Bay (northern Québec, Canada), marine fish exhibited 2 distinct reproduction strategies. Sand lance Ammodytes sp. and Arctic cod Boreogadus saida produced large numbers of small larvae that hatched before the ice break-up when the abundance of prey (copepod eggs and nauplii) was low. Feeding incidence was low and the larvae fed on relatively small prey. A morphometric index of condition suggested that the 2 species suffered from starvation at first feeding. This critical period was approximately synchronized with peak abundance of prey, possibly an adaptation to minimize starvation mortality. Stichaeidae and Cottidae produced small numbers of large larvae that fed efficiently on relatively large prey before yolk resorption. These larvae emerged after the ice break-up, when phytoplankton production was well under way and prey were abundant. Interannual variations in the timing between first feeding and the production of prey could influence recruitment in sand lance and Arctic cod but are unlikely to affect the early survival of Stichaeidae and Cottidae.
\end{abstract}

\section{INTRODUCTION}

Mortality in marine fish larvae and early postlarvae is typically high during the first weeks of planktonic life (May 1974, Dahlberg 1979, Leiby 1984) and is believed to result primarily from starvation and predation (Hunter 1976, Leggett 1986, Anderson 1988). In addition to its direct impact on survival, starvation increases vulnerability to predators (Wyatt 1972, Bailey \& Yen 1983, Bailey 1984, Purcell et al. 1987, Yin \& Blaxter 1987 ) and, by slowing growth, could also increase the duration of the period during which the larvae suffer from predation (Cushing 1974, Ware 1975, Shepherd \& Cushing 1980, Anderson 1988).

The critical period hypothesis (Hjort 1914) proposes that fish larvae are vulnerable to starvation primarily at yolk resorption when the transition from endogenous to exogenous feeding occurs. During this transition the larva must find enough food to fulfill increasing metabolic demand at a time when swimming capacities and foraging skills are not fully developed. In the sea, a scarcity of suitable prey at first feeding could result in a

\footnotetext{
- Contribution to the research programs of GIROQ (Groupe interuniversitaire de recherches océanographiques du Québec) and Institut Maurice-Lamontagne (Department of Fisheries and Oceans Canada)
}

massive mortality that could ultimately affect yearclass strength (Hjort 1914). In support of the hypothesis, emaciation and/or poor physiological condition have been observed most often in first-feeding postlarvae that had recently exhausted their yolk reserves (Shelbourne 1957, O'Connell 1980, Westernhagen \& Rosenthal 1981, Grover \& Olla 1986, Theilacker 1986, Setzler-Hamilton et al. 1987, Bolduc 1990). While it remains to be demonstrated that first feeding is the last survival bottleneck determining year-class strength (Marr 1956, May 1974, Leggett 1986), these results support the view that starvation mortality operates primarily during early postlarval life, before the fish become efficient predators.

In order to minimize starvation mortality at first feeding, spawning strategies of fish should allow for any critical period ensuing from yolk resorption to coincide with peak abundance of prey organisms of the right kind and size. This timing could be particularly critical in ice-covered seas where the production season is short and prey diversity may be low (Cushing 1975). Such areas are characterized by 2 distinct production cycles: the bloom of ice algae taking place in bottom ice and at the ice-water interface, and the phytoplankton bloom which occurs in the water column after ice break-up (e.g. Tremblay et al. 1989). 
This study documents the seasonal occurrence of fish larvae in relation to the production of algae and the reproduction of copepods in southeastern Hudson Bay. The feeding ecology and relative physiological condition of the larvae are compared to the seasonal production of their prey. In particular, we address the hypothesis that starvation occurs primarily in the days following yolk resorption and that this critical period coincides with peak production of food resource.

\section{MATERIALS AND METHODS}

The study was conducted off Kuujjuarapik in southeastern Hudson Bay (Fig. 1) from 24 April to 14 June 1988. The main hydrographic feature of the area in winter and early spring is the brackish plume formed by the discharge of the Great Whale River under the ice cover on the Bay. From February to April, the volume of the freshwater outflow ranges from 135 to $200 \mathrm{~m}^{3} \mathrm{~s}^{-1}$ (Ingram \& Larouche 1987). At the freshet in May, discharge increases to $910 \mathrm{~m}^{3} \mathrm{~s}^{-1}$, and with the ice cover reducing friction and wind mixing the plume extends NNE over $1000 \mathrm{~km}^{2}$ with an average thickness of about $5 \mathrm{~m}$ (Ingram 1981, Ingram \& Larouche 1987).

Biological production in the area starts in early April with the development of microalgae at the ice-water interface (Gosselin et al. 1985). The microflora at the bottom of the ice is exploited by different organisms living in the ice matrix itself, including bacteria, nematodes, amphipods and harpacticoid copepods (Grainger 1988). Pelagic herbivore copepods also migrate to the ice-water interface to graze on the microalgae (see Runge et al. in press for a review). Production of phytoplankton in the water column is low during the ice-algal bloom and increases 4 to $6 \mathrm{wk}$ later at the time of, or after, the ice break-up in late May or early June (Legendre et al. 1981).

Four sampling stations were located at $5 \mathrm{~km}$ intervals on first-year ice along a northward transect which encompassed the salinity gradient associated with the river plume (Fig. 1). Between-station variability is discussed elsewhere (Gilbert 1991). In the present study, we consider only the seasonal pattern of variations. Zooplankton and ichthyoplankton abundances presented here are arithmetic means of the 4 stations.

Meteorological conditions permitting, ice stations were visited every third day from 24 April until 18 May when the ice pack began to break up. Fish larvae and zooplankton were sampled under the ice using two $500 \mu \mathrm{m}$ mesh nets $\left(1 \mathrm{~m}^{2}\right.$ mouth opening) mounted on a metal frame. The frame was attached to a cable forming a loop between 2 holes separated by $200 \mathrm{~m}$ and a heavy duty snowmobile was used to tow the sampler at a speed of 2.5 knots. Free-wheeling spherical buoys

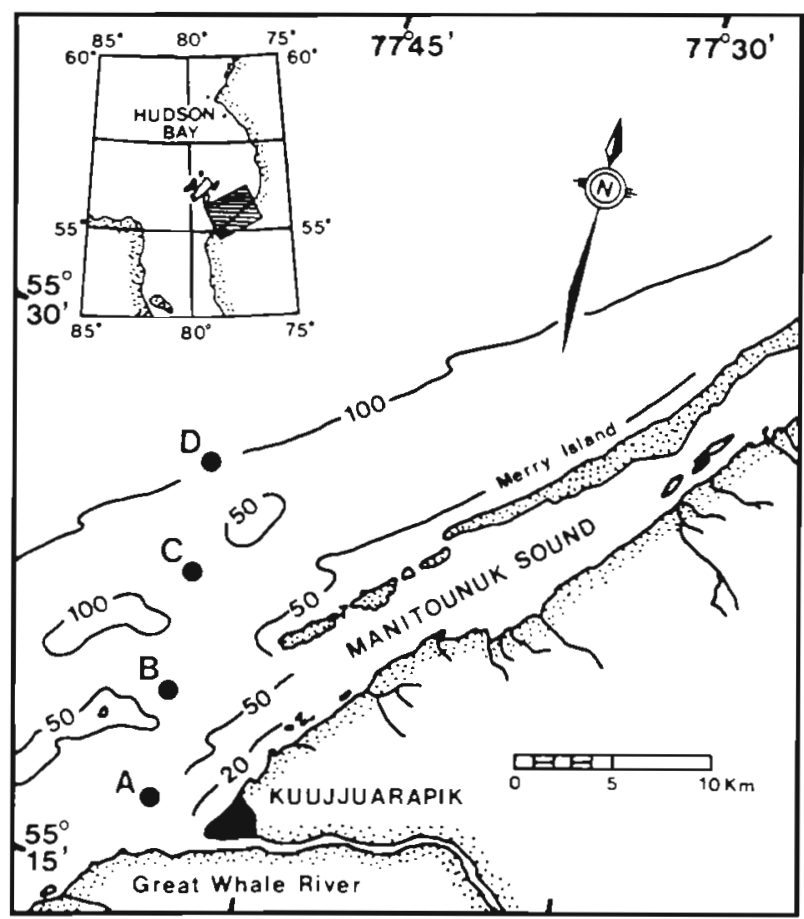

Fig. 1. Southeastern Hudson Bay, Canada, showing positions of sampling stations. Isobaths are in metres

mounted on the frame kept the sampler immediately under the ice to sample the 0.5 to $1.5 \mathrm{~m}$ depth layer. Removing the buays allowed sampling of the deeper marine layer in the depth range 8 to $10 \mathrm{~m}$. Both layers were sampled at each station. The nets were equipped with TSK flowmeters. A time-depth recorder was mounted on the frame to record sampling depth. The average volume of water filtered by each net was $159 \mathrm{~m}^{3}$ (standard deviation $=26 \mathrm{~m}^{3}$ ). When the ice started to break after 18 May, sampling was pursued every second day until 14 June using a helicopter to reach open waters in the vicinity of the original stations. The helicopter, mounted on floats, alighted on the water in ice-free areas and was used (somewhat like a boat) to tow a conical net ( $1 \mathrm{~m}$ diameter, $500 \mu \mathrm{m}$ mesh), first in the surface layer, and then at about $8 \mathrm{~m}$. The average volume of water filtered per tow was $539 \mathrm{~m}^{3}$ (standard deviation $=145 \mathrm{~m}^{3}$ ). To estimate microplankton abundance, vertical tows from the bottom to the surface were carried out at each station with a 64 um mesh standard net. Plankton samples were preserved in $4 \%$ buffered formalin. To attenuate gut content evacuation, fish larvae were anesthetized with MS-222 before fixation.

Samples for the determination of algal biomass at the ice-water interface were collected by Scuba divers using a suction gun (2.2 I syringe, $5 \mathrm{~cm}$ diameter) along transects of known width and length (Tremblay et al. 1989). To estimate phytoplankton biomass in the water column, samples were collected at different depths 
with a submersible pump (flow rate $131 \mathrm{~min}^{-1}$; hose diameter $6.5 \mathrm{~mm}$ ). Samples were filtered on Whatman $\mathrm{GF} / \mathrm{F}$ filters and chlorophyll a concentrations were determined by a fluorometric method after $24 \mathrm{~h}$ extraction in $90 \%$ acetone at $5^{\circ} \mathrm{C}$ (Parsons et al. 1984). Vertical profiles of salinity and temperature were recorded with a CTD profiler.

All fish larvae were sorted from the $500 \mu \mathrm{m}$ mesh net samples. A subset of larvae of the most abundant species were selected for gut content analysis. Prey were excised, measured (width and length) and identified when possible. Microplankton taxa were enumerated in the $64 \mu \mathrm{m}$ mesh standard net samples. Following Fortier \& Harris (1989) the food resource (in $\mathrm{mg}$ $\mathrm{m}^{-3}$ ) available for larvae of a given species was defined as:

$$
\sum D_{i} F_{i} W_{i} \text { for } i=1,2, \ldots, n
$$

where $D_{i}, F_{i}$ and $W_{1}$ are respectively the density of prey $i$ in the environment (numbers $\mathrm{m}^{-3}$ ), its frequency in the gut content of the larvae, and its average weight (mg). The $n$ prey taxa representing at least $2 \%$ of the composition of the diet of the species were included in the sum.

Total length and body height above the anus were measured on intact larvae. Fish larvae may shrink gradually during long-term preservation in formalin (e.g. Kruse \& Dalley 1990, Jennings 1991). To avoid a systematic bias in morphometric measurements, all larvae were measured within an interval of 6 to $8 \mathrm{wk}$ after capture and fixation. The residuals of the linear regression of body height above the anus (a dimension sensitive to starvation) against total length (a dimension less sensitive to starvation) were used to assess the relative emaciation of the yolk-sac larvae and postlarvae of a given species (Wyatt 1972, Ehrlich et al. 1976, Koslow et al. 1985, Nielson et al. 1986, Yin \& Blaxter 1986). Negative residuals indicated larvae in poor condition relative to the overall average condition of the population during the sampling season. Comparative studies have shown that morphometric indices are generally good indicators of true condition as measured by histological or biochemical indices or of the known condition of starved larvae (Ehrlich et al. 1976, Nielson et al. 1986, Theilacker 1986, Yin \& Blaxter 1986, SetzlerHamilton et al. 1987).

\section{RESULTS}

\section{Hydrography}

Hydrographic conditions at Stn C illustrated the seasonal changes in the structure of the water column in the sampling area (Fig. 2). A small temperature gra- dient $\left(0\right.$ to $\left.-1.0^{\circ} \mathrm{C}\right)$ existed until mid-May within the surface layer $(0$ to $5 \mathrm{~m})$. Some warming of the water column was observed in early June. Stratification however resulted primarily from the strong vertical gradient in salinity caused by the plume of the Great Whale River under the ice cover. The steep halocline was centered at $2.5 \mathrm{~m}$ in April and deepened to $5 \mathrm{~m}$ due to ice melt and the river freshet from 8 May onwards. By 18 May, the ice cover on the bay started to break. Stratification weakened in late May and early June due to increased wind mixing after the ice break-up.

\section{Algal production, copepod reproduction, and larval fish occurrence}

The development of ice algae took place several weeks before the phytoplankton bloom (Fig. 3). Algal density at the ice-water interface reached a maximum on 23 April and decreased rapidly thereafter (Fig. 3a). This decline in biomass coincided with the first melting of the ice and the massive input of freshwater in the bay following the freshet of the Great Whale River on 8 May. The loss of cells from the ice-water interface was well coupled with an increase in chlorophyll in the brackish layer $(0$ to $2 \mathrm{~m}$ ) immediately under the ice (Fig. $3 \mathrm{~b})$. The phytoplankton bloom in the saline layer $(>5 \mathrm{~m}$ ) started in early June after the ice break-up, some 5 to $6 \mathrm{wk}$ later than the blooming of the ice algae (Fig. 3c).

Copepods were the major and most diversified component of the zooplankton assemblage in the standard net collections (Table 1). Copepod eggs and nauplii dominated the microzooplankton. Only the larger forms of tintinnids were retained by the net. Copepods

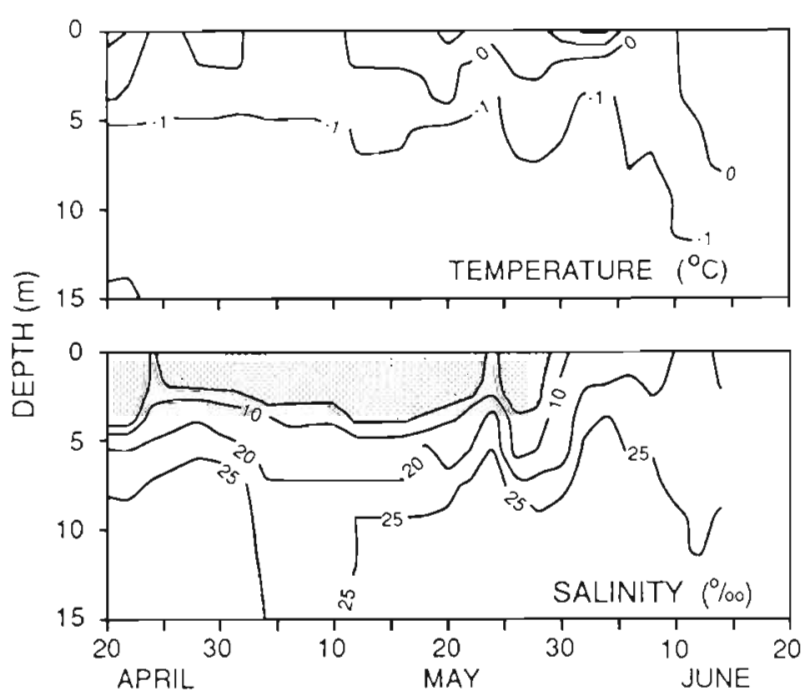

Fig. 2. Time-depth distribution of isotherms and isohalines in the surface layer $(0$ to $15 \mathrm{~m}$ ) at $\operatorname{Stn} \mathrm{C}$ (water depth $=50 \mathrm{~m}$ ) 
and copepodites of Oithona simills, Oncea borealis, Pseudocalanus spp., and Microcalanus pygmaeus made up the bulk of the mesozooplankton. The relative scarcity of large forms such as Calanus glacialis and Metridia longa may reflect avoidance of the standard net but their abundance was also low in collections with more efficient samplers (Ponton \& Fortier unpubl.) The macrozooplankton fraction was dominated by the chaetognath Sagitta elegans. Cnidaria and ctenaria were also abundant (up to 10 individuals per sample) but identification and precise estimates of their abundance were difficult because of poor condition. Euphausids which probably avoided the net were captured in very low numbers.

Copepodites of the dominant species increased in number in late April, following the end of the diapause and the vernal submergence (Fig. 3d). The density of female copepods remained low until late May, when their numbers started to rise rapidly with the final molting of copepodites (Fig. 3e). The production of 'free' eggs (i.e. eggs that are released by the female in the water column) started as early as 10 May and reached a maximum in early June (Fig. 3f). The density of free eggs and nauplii increased in direct proportion to female abundance (Fig. 3f, g).

The ichthyoplankton assemblage comprised 11 marine species, 2 anadromous species (cisco and lake whitefish) and 1 species of freshwater origin (burbot) (Table 2). The ecology and distribution of species represented by a total of 50 larvae or less will not be considered in detail. Sand lance and Arctic cod dominated numerically. The length-frequency distributions of the different species presented a single mode, suggesting that only 1 cohort of larvae was produced during the sampling period (Fig. 4). In most species, the small range of lengths observed over a period of nearly 2 mo indicated that growth was particularly slow. Yolk resorption occurred between 7 and $10 \mathrm{~mm}$ for sand lance and between 5.5 and $8.5 \mathrm{~mm}$ for Arctic cod (Fig. 4a, b). All burbot were small yolk-sac larvae (Fig. 4c). At hatching, the larvae of Stichaeidae (Arctic shanny and slender eelblenny) were relatively large with an average length for yolk-sac larvae of 10.8 and $16.6 \mathrm{~mm}$ respectively (Fig. $4 \mathrm{~d}$, e). The 3 abundant sculpins presented a similar range of length (8 to $14 \mathrm{~mm})$ and the large majority of them $(\geq 90 \%)$ were yolk-sac larvae (Fig. 4f, g, h).

Sand lance and Arctic cod larvae hatched before the ice break-up. Larvae and early postlarvae were collected over the entire sampling period, but in lower numbers in late May and early June (Fig. 5a, b). Burbot larvae originated from the Great Whale River and were captured from late April until 23 May when river runoff decreased (Fig. 5c). The absence of capture after 23 May suggested that this freshwater species did not
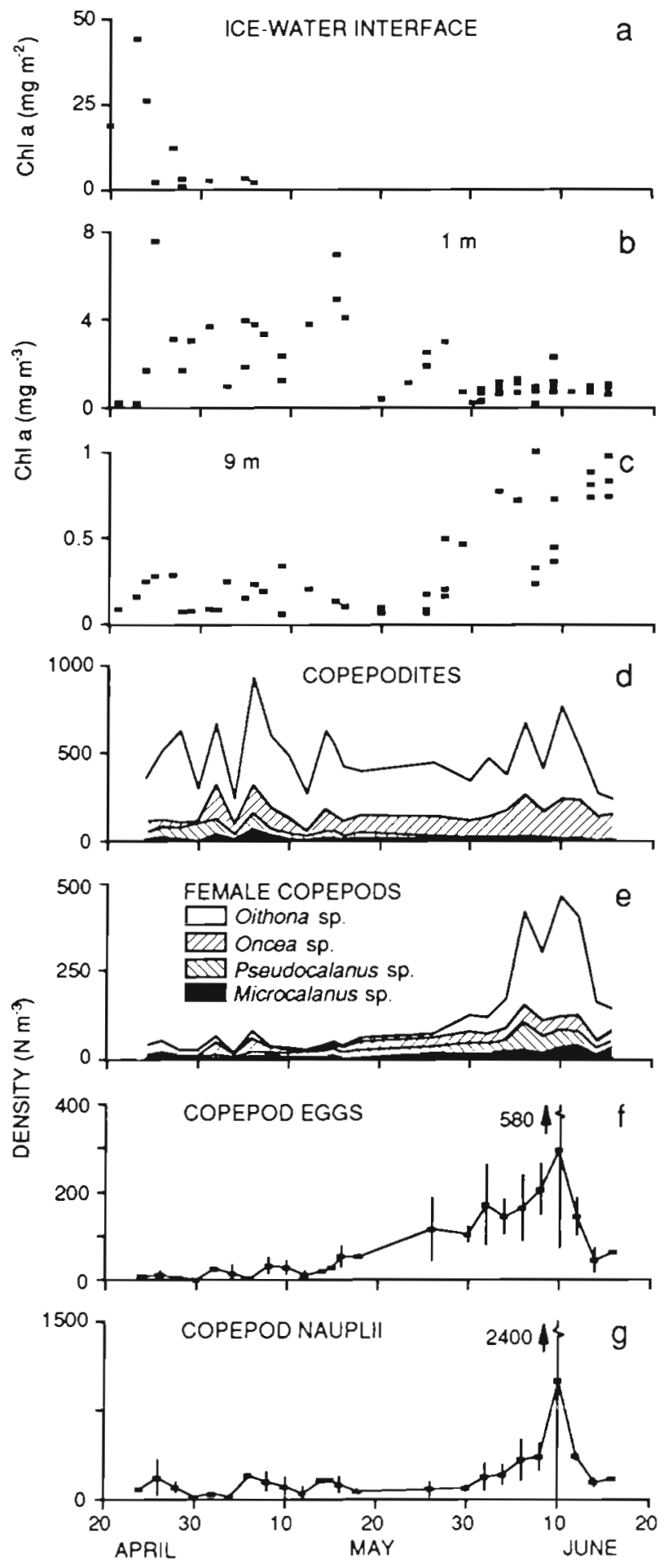

Fig. 3. (a to c) Seasonal variations in the concentration of chlorophyll $a$ at the ice-water interface, in the surface layer $(1 \mathrm{~m})$, and in the deeper marine layer $(9 \mathrm{~m})$. ( $\mathrm{d}$ to g) Seasonal variations in the density of copepodites and female copepods of the dominant species, copepod eggs and copepod nauplii. Chlorophyll a values from the 4 stations were pooled, note the different scales according to depth. Zooplankton densities are the average at date for the 4 stations 
Table 1. Composition of the zooplankton in southeastern Hudson Bay in spring 1988. Average density (numbers $\mathrm{m}^{-3}$ ) of the different taxa collected in bottom-to-surface tows ( $64 \mu \mathrm{m}$ mesh standard net) taken at 4 stations at 2 to $3 \mathrm{~d}$ intervals from $24 \mathrm{April}$ to 14 June $(n=65$ samples $)$

$\begin{array}{lr}\text { Copepod nauplii } & 196.5 \\ \text { Copepod eggs (free eggs) } & 87.4 \\ \text { Tintinnids } & 6.7 \\ \text { Echinoderm larvae } & 4.1 \\ \text { Gastropod larvae } & 2.4 \\ \text { Rotifers } & 1.4 \\ \text { Appendicularian } & 1.0 \\ \text { Euphausiid nauplii } & 0.8 \\ \text { Veliger larvae } & 0.4 \\ \text { Copepods: } & \end{array}$

Oithona similis 403.9

Oncea borealis 295.7

Pseudocalanus spp. $\quad 78.8$

Microcalanus pygmaeus $\quad 36.6$

Acartia longiremis $\quad 1.0$

Calanus glacialis 1.0

Metridia longa $\quad 0.2$

Harpacticoid copepods $\quad 0.9$

Unidentified copepods $\quad 13.1$

Sagitta elegans $\quad 3.2$

Cnidaria and Ctenaria $\quad 3.0$

Polychaeta 0.9

Amphipoda $\quad 0.1$

Males Females Copepodites

$22.9 \quad 77.7 \quad 303.3$

$\begin{array}{lll}156.6 & 23.2 & 115.9\end{array}$

$29.3 \quad 24.3 \quad 25.2$

$\begin{array}{lll}0 & 17.1 & 19.5\end{array}$

$\begin{array}{lll}0.3 & 0.4 & 0.3\end{array}$

$\begin{array}{lll}<0.1 & 0.2 & 0.7\end{array}$

$0.1<0.1<0.1$

- Includes $P$. minutus, P. newmani Frost and $P$. acuspes (Giesbrecht)

survive in the Bay. Arctic shanny first occurred at ice break-up in mid-May and their number increased until the end of sampling (Fig. 5d). Slender eelblenny larvae appeared in early May, became most abundant in late May, and were captured until the end of sampling in June (Fig. 5e). A few fourhorn and Arctic staghorn sculpins were sampled as early as mid-May but most of them emerged in late May and early June, about $2 \mathrm{wk}$ after the break-up of the ice cover on the Bay (Fig. 5f, g). The less abundant Arctic sculpin also emerged $2 \mathrm{wk}$ after break-up (Fig. 5h).

\section{Larval fish feeding}

Except for Arctic shanny, fish larvae preyed primarily on immature stages of copepods (Table 3). Sand lance and Arctic cod exploited the same prey assemblage but algal cells and tintinnids were more frequent in the diet of sand lance than Arctic cod. Ingested algal cells were too damaged to ascertain whether they originated from the phytoplankton or the ice algae assemblage. Arctic shanny fed on rotifers that were distributed in the brackish surface layer and also on large crustacean eggs and nauplii. Based on their size $(>200 \mu \mathrm{m})$ these were tentatively identified as euphausiid eggs and nauplii. Mollusk larvae represented a substantial per- centage of the diet of small fourhorn sculpin larvae. The diet of the relatively large slender eelblenny included copepodites. Burbot larvae did not feed.

Feeding incidence and the average number of prey in positive gut content remained low in sand lance yolk-sac larvae (Table 4). Feeding improved only slightly in the postlarval stage. Arctic cod fed poorly until they resorbed their yolk reserve or reached a length of $8 \mathrm{~mm}$. Both species fed on relatively small preys, the average width of prey ranging from 43 to $70 \mu \mathrm{m}$ in sand lance and 82 to $103 \mu \mathrm{m}$ in Arctic cod, depending on larval length. Yolk-sac and postlarval Arctic shanny were capable of ingesting several large preys (Table 4). Yolk-sac slender eelblenny fed frequently but captured few prey until they lost their yolk sac or reached a length of $18 \mathrm{~mm}$. A high percentage of the different sculpins fed during the yolk-sac or postlarval stages and these species were able to capture relatively high numbers of relatively large prey (Table 4).

\section{Food availability and physiological condition of fish larvae}

Body height above the anus increased linearly with standard length in sand lance and Arctic cod (Fig. 6, 
Table 2. The ichthyoplankton assemblage sampled in southeastern Hudson Bay in spring 1988. The early developmental stages of some groups are poorly described in the literature. Uncertain identification is denoted by a question mark

\begin{tabular}{|c|c|c|c|}
\hline Species & Common name & Number caught & $\begin{array}{c}\text { Average density } \\
\left(\text { per } 1000 \mathrm{~m}^{3} \text { ) }\right.\end{array}$ \\
\hline Ammodytes sp. & Sand lance & 1148 & 51.5 \\
\hline Boreogadus saida & Arctic cod & 907 & 46.2 \\
\hline Stichaeus punctatus & Arctic shanny & 252 & 10.0 \\
\hline Lota lota & Burbot & 178 & 5.8 \\
\hline Myoxocephalus quadricornis? & Fourhorn sculpin & 101 & 1.6 \\
\hline Gymnocanthus tricuspis & Arctic staghorn sculpin & 79 & 1.8 \\
\hline Lumpenus fabricii? & Slender eelblenny & 77 & 1.5 \\
\hline Myoxocephalus scorpioides? & Arctic sculpin & 26 & 0.5 \\
\hline Mallotus villosus & Capelin & 25 & 0.8 \\
\hline Liparis fabricii? & Gelatinous snailfish & 20 & 0.7 \\
\hline Coregonus artedii & Cisco & 17 & 0.7 \\
\hline Coregonus clupeaformis & Lake whitefish & 4 & 0.1 \\
\hline Triglops sp. & Mailed sculpin? & 3 & $<0.1$ \\
\hline Icelus sp. & Twohorn sculpin? & 3 & $<0.1$ \\
\hline
\end{tabular}

Table 5). The residuals of the regression presented no trend, either for yolk-sac larvae or for postlarvae (Fig. 6), indicating that the relationship between body height and length was correctly described by the same regression equation for the 2 developmental stages. Body height increased linearly with standard length in slender eelblenny and the 3 abundant species of sculpins, but the regression was not statistically significant for Arctic shanny (Table 5).

Yolk-sac frequency decreased linearly with time in sand lance larvae (Fig. 7a). Yolk-sac resorption at the level of the population (50\% of the larvae with no more yolk) occurred in early June. Potential food resource for this species developed slowly until the end of May and then increased rapidly to reach a maximum on 10 June (Fig. 7b). The relative physiological condition of yolksac and postlarval sand lance remained at or above the seasonal average until 30 May (Fig. $7 \mathrm{C}$, d). After that date, several larvae presented signs of emaciation and mean condition was below average. Individuals captured after 8 June were in relatively good condition (Fig. $7 \mathrm{c}, \mathrm{d}$ ). In summary, the relative condition of sand lance larvae was minimum in the first week of June, immediately before food availability reached a maximum.

A similar scenario was observed in Arctic cod (Fig. 8). Yolk-sac resorption occurred in mid-May, ca $2 \mathrm{wk}$ before sand lance (Fig. 8a). Larvae in poorer condition than the seasonal average occurred from 23 May onward, slightly earlier than in sand lance (Fig. $8 \mathrm{C}, \mathrm{d}$ ). Condition started to improve around 4 June. The few postlarvae sampled after this period were in good condition. As in sand lance, the relative physiological condition of the overall population reached a minimum as food resource started to increase.

Little evidence of a critical period was found in the relative condition of species that emerged after the break-up of the ice in the Bay. Contrary to sand lance and Arctic cod, the temporal distribution of the relative physiological condition for these species showed little trend except for a tendency to increase with time in slender eelblenny (Fig. 9).

\section{DISCUSSION}

\section{Algal production and copepod reproduction in subarctic Hudson Bay}

The development of a dense algal mat at the icewater interface in early spring, followed $6 \mathrm{wk}$ later by the phytoplankton bloom in the water column, was typical of the double production cycle often observed in seasonally ice-covered Arctic and subarctic waters (e.g. Gosselin et al. 1985, Tremblay et al. 1989). The production of copepod eggs and nauplii started as soon as 10 May, when chlorophyll a concentrations in the saline layer were lower $\left(<0.4 \mathrm{mg} \mathrm{m}^{-3}\right)$ than levels known to trigger spawning in copepods (> $1.6 \mathrm{mg} \mathrm{m}^{-3}$ ) (Kiorboe et al. 1988). This is consistent with the hypothesis that some copepods exploit the ice algae growing at the ice-water interface or sedimenting in the diluted surface layer to hasten reproduction (e.g. Runge \& Ingram 1988).

In southeastern Hudson Bay, Calanus glacialis, Pseudocalanus spp. and Oithona similis are the dominant copepods that reproduce under the ice before the phytoplankton bloom (Runge et al. in press). Female Calanus glacialis and Pseudocalanus spp. migrate towards the ice-water interface at night to feed, but the primary source of nutrition for increased reproduction appears to be sedimenting ice algae (Runge \& Ingram 
1991, Runge et al. in press). Since copepod eggs and nauplii are the main prey of first-feeding sand lance (Monteleone \& Peterson 1986, this study) and Arctic cod (Ponomarenko 1967, this study), the bulk of whatever food is available to these species before the ice break-up and the phytoplankton bloom probably originates in ice algae production.

Maximum abundance of copepod eggs and nauplii in late May and June coincided with higher algal biomass in the deeper saline layer, suggesting that copepod reproduction after the ice break-up increased primarily in response to the phytoplankton bloom. Yet, based on energetics, Tourangeau \& Runge (1991) and Runge et al. (in press) argue that grazing on ice algae contributes significantly to the maturation of the oocytes, therefore enabling female copepods to rapidly convert sedimenting ice algae into egg production at ice melt and to reach maximum production rates before the phytoplankton bloom. Thus, the production of larval fish food at the time of the phytoplankton bloom would be at least in part rooted in the bloom of ice algae.

\section{A critical period (sensu Hjort 1914) in subarctic fish larvae?}

Because of the coarse temporal scales often used in surveys of fish eggs and larvae, attempts at demonstrating the existence of a critical period based on survival curves have been generally inconclusive (Marr 1956, May 1974, Dahlberg 1979, Fortier \& Leggett 1985, Leggett 1986). Yet, several field studies using morphometric, histological, or biochemical indices of condition have detected significant percentages of emaciated first-feeding larvae in the sea and the occurrence of starvation or poor condition has often been related to local minima in prey availability (Shelbourne 1957, Nakai et al. 1969, O'Connell 1980, Westernhagen \& Rosenthal 1981, Koslow et al. 1985, Grover \& Olla 1986, Theilacker 1986, Buckley \& Lough 1987, Nakata 1988, Håkanson 1989).

The morphometric index used in the present study did not allow the quantification of the absolute condition of the larvae, but enabled us to detect whether larvae in poorer condition than average were distributed uniformly over the season or were concentrated in a specific period. Our results generally support the hypothesis of a critical period in pelagic Arctic cod and sand lance but not in coastal-demersal Stichaeidae or Cottidae. Sand lance and Arctic cod postlarvae in rela-

Fig. 4. Length-frequency distributions of yolk-sac larvae (black bars) and postlarvae (open bars) of the dominant fish species captured from 24 April to 14 June 1988. Average lengths $(X)$ and samples sizes $(n)$ are given
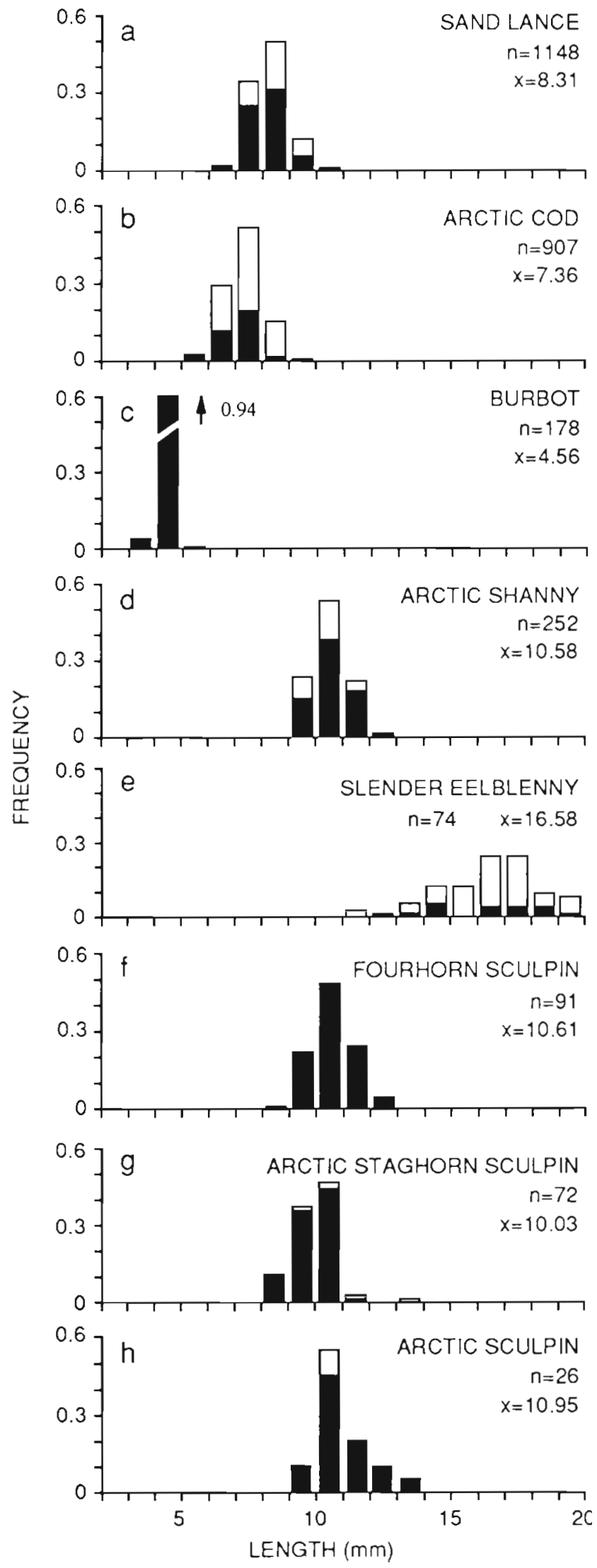


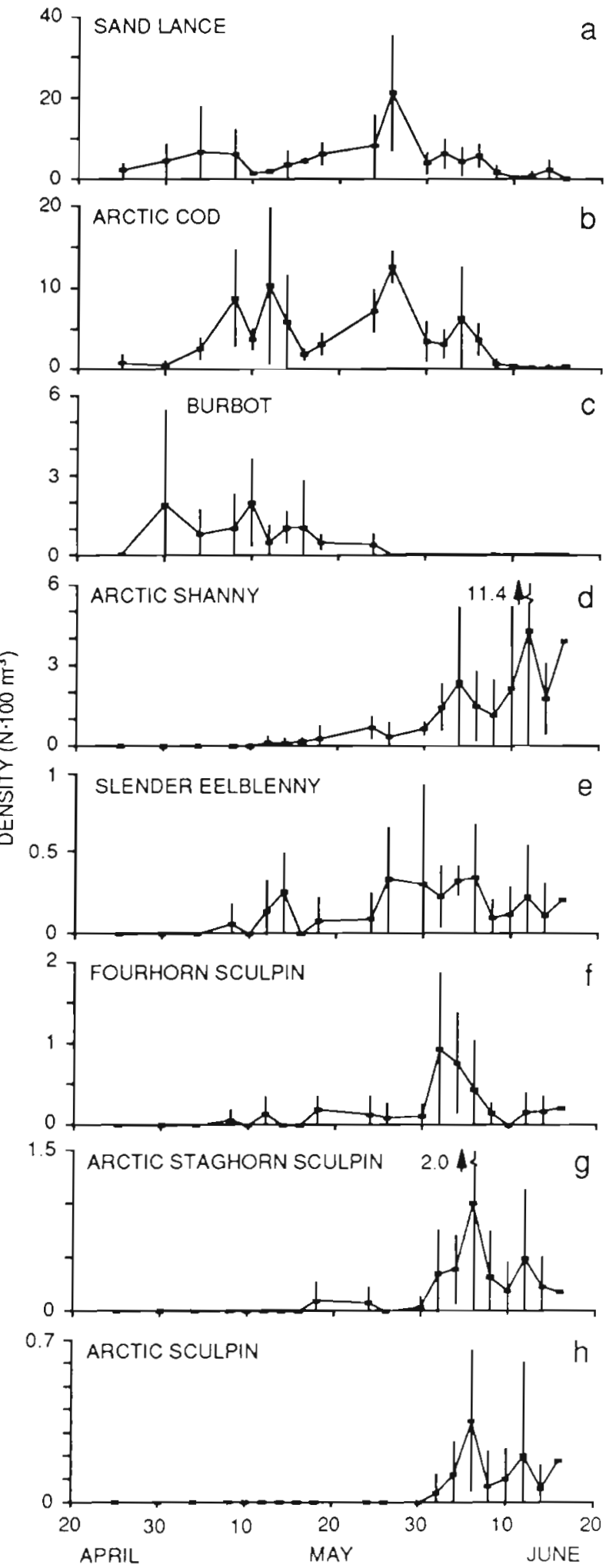

Fig. 5. Seasonal variations in the density of the dominant larval fish species. Values are the average at date for the 4 stations. Vertical bars represent standard deviations tively poor condition occurred primarily during a short period of $1 \mathrm{wk}$ in the days that followed yolk-sac resorption at the population level. This period of relative emaciation took place as the food resource of the larvae started to develop and about 1 wk before it reached maximum availability. Contrary to expectations, the fraction of the population classified as 'yolksac' also presented signs of emaciation. In fact, yolk-sac larvae of both species retained only traces of yolk at the time when $50 \%$ of the fish had totally exhausted their yolk (i.e. yolk-sac resorption at the population level). These last remnants of yolk were apparently insufficient to maintain the larvae in good condition. In both species, the few larvae that survived the critical period were in above-average condition, suggesting either that larvae in poor condition were eliminated or that condition improved with increasing food availability.

\section{Ice break-up and recruitment}

Our results indicate that the early survival and recruitment of sand lance and Arctic cod could hinge on the timing between first feeding of the larvae and the production of their prey as proposed by the critical period hypothesis (Hjort 1914). Runge et al. (in press) hypothesized that variability in the timing and magnitude of the ice algal bloom influences the productivity cycles of Calanus and Pseudocalanus in southeastern Hudson Bay and consequently the timing of food availability to larvae of Arctic cod and sand lance' The present study confirms that any under-ice feeding by sand lance or Arctic cod larvae depends ultimately on the production of ice algae. However, the 2 species feed little before yolk-sac resorption which, in 1988, was completed at or soon after ice break-up. Firstfeeding and the associated critical period occurred after the ice break-up, coincident with the phytoplankton bloom and the main reproductive effort of copepods. As discussed above, the relative contributions of ice algae and phytoplankton in fueling the reproduction of copepods remain to be evaluated. Indications are however that the timing of the phytoplankton bloom triggered by the ice break-up plays a critical role in the match between first-feeding larvae and their food.

The time of first feeding depends essentially on the development rate of the eggs and larvae under the ice. which in turn depends on ambient temperature. Before break-up, temperatures under the ice are low $1-1$ to $0^{\circ} \mathrm{C}$ ) and vary very little due to the isolating effect of the ice sheet (Lepage \& Ingram 1991). Given this stability of the under-ice temperature regime, little interannual variability is expected in the developmental rate of sand lance and Arctic cod, and it is reasonable to 


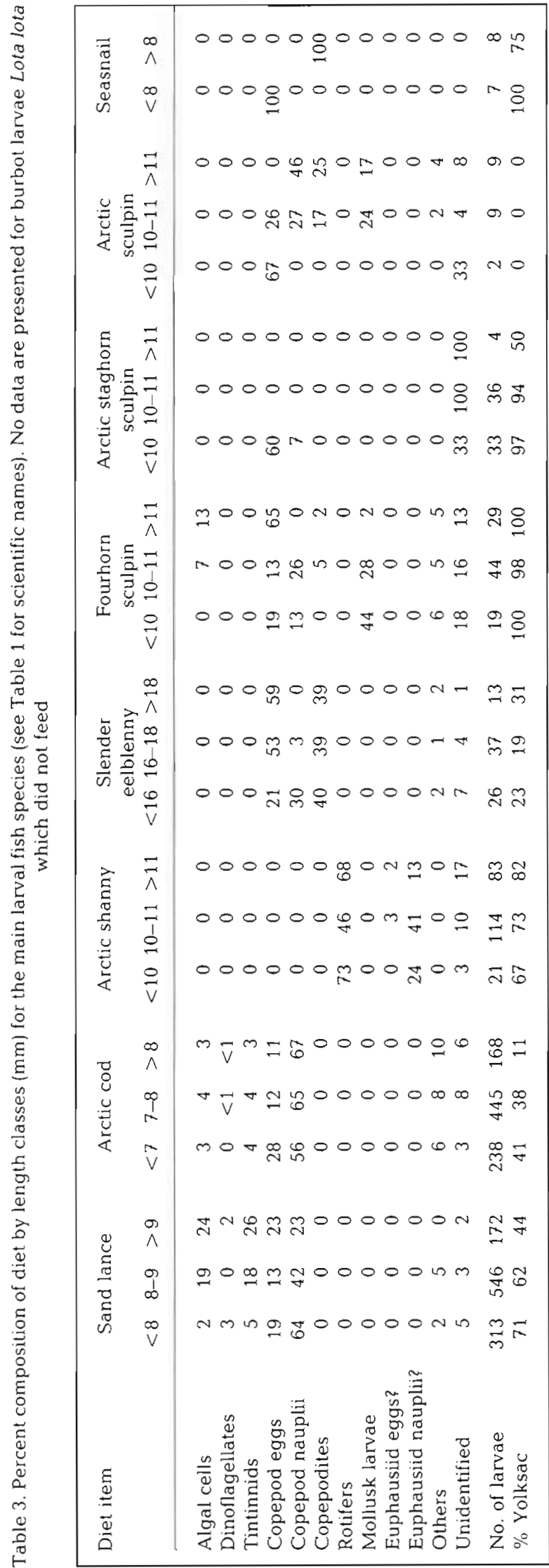

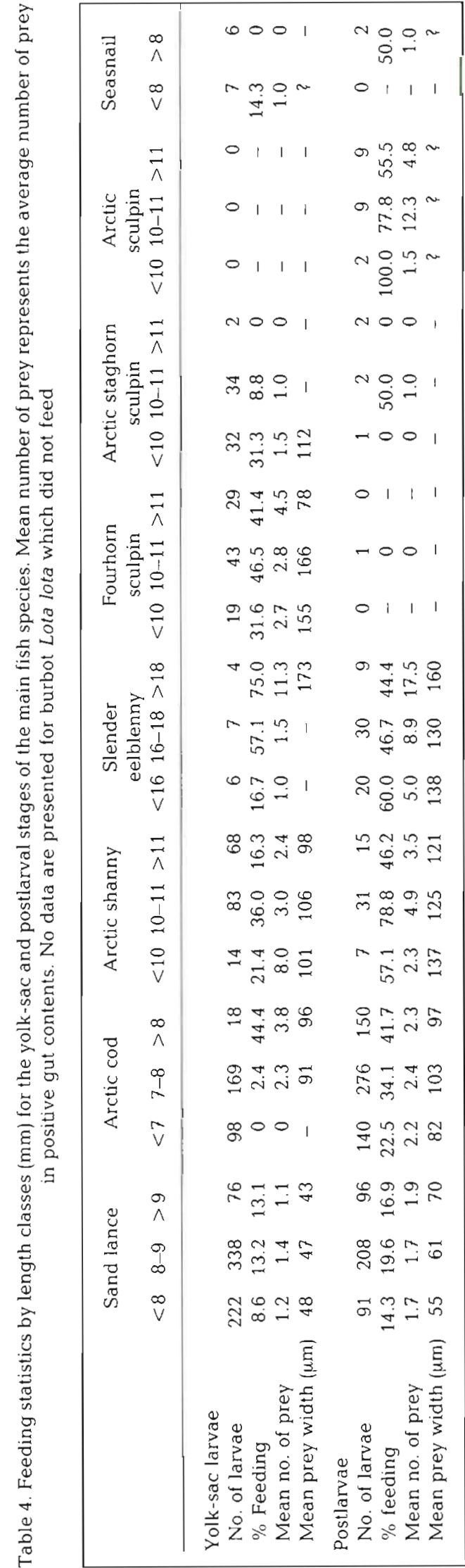




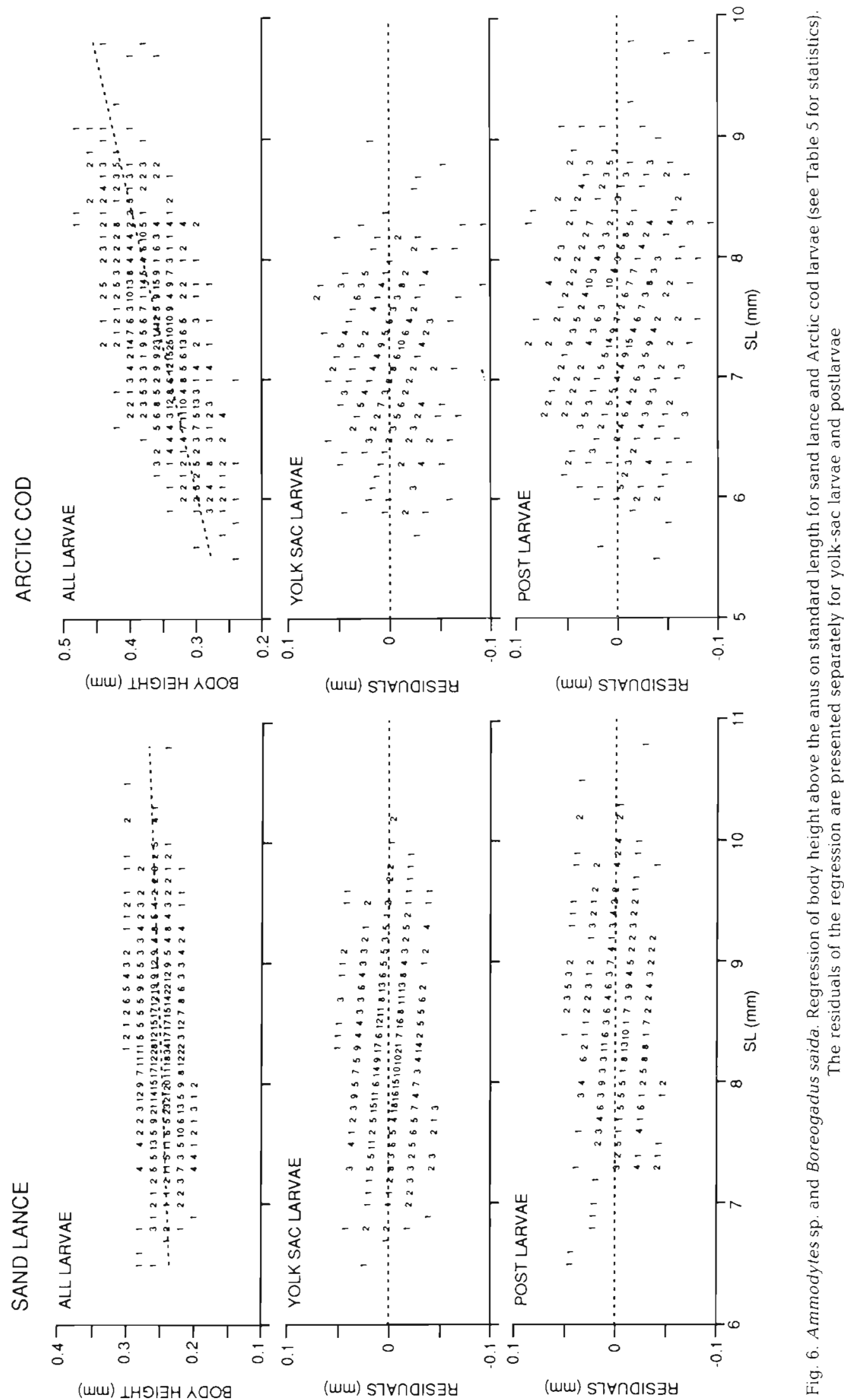


Table 5. Statistics of regression of body height above the anus on standard length for the main larval fish species

\begin{tabular}{|lrrrrrr}
\hline Species & Intercept & Slope & $\mathrm{n}$ & $F$ & $\mathrm{p}$ & $\mathrm{r}$ \\
\hline Sand lance & 0.1854 & 0.0077 & 956 & 55.4 & $<0.0001$ & 0.2341 \\
Arctic cod & 0.0545 & 0.0408 & 816 & 607.6 & $<0.0001$ & 0.6535 \\
Arctic shanny & 0.5612 & 0.0005 & 204 & 0.013 & 0.9101 & 0.0100 \\
Slender eelblenny & 0.1542 & 0.0364 & 43 & 42.2 & $<0.0001$ & 0.7079 \\
Fourhorn sculpin & 0.1407 & 0.0678 & 70 & 46.7 & $<0.0001$ & 0.6354 \\
Arctic staghorn sculpin & 0.5059 & 0.0182 & 55 & 6.1 & 0.0167 & 0.3186 \\
\hline
\end{tabular}
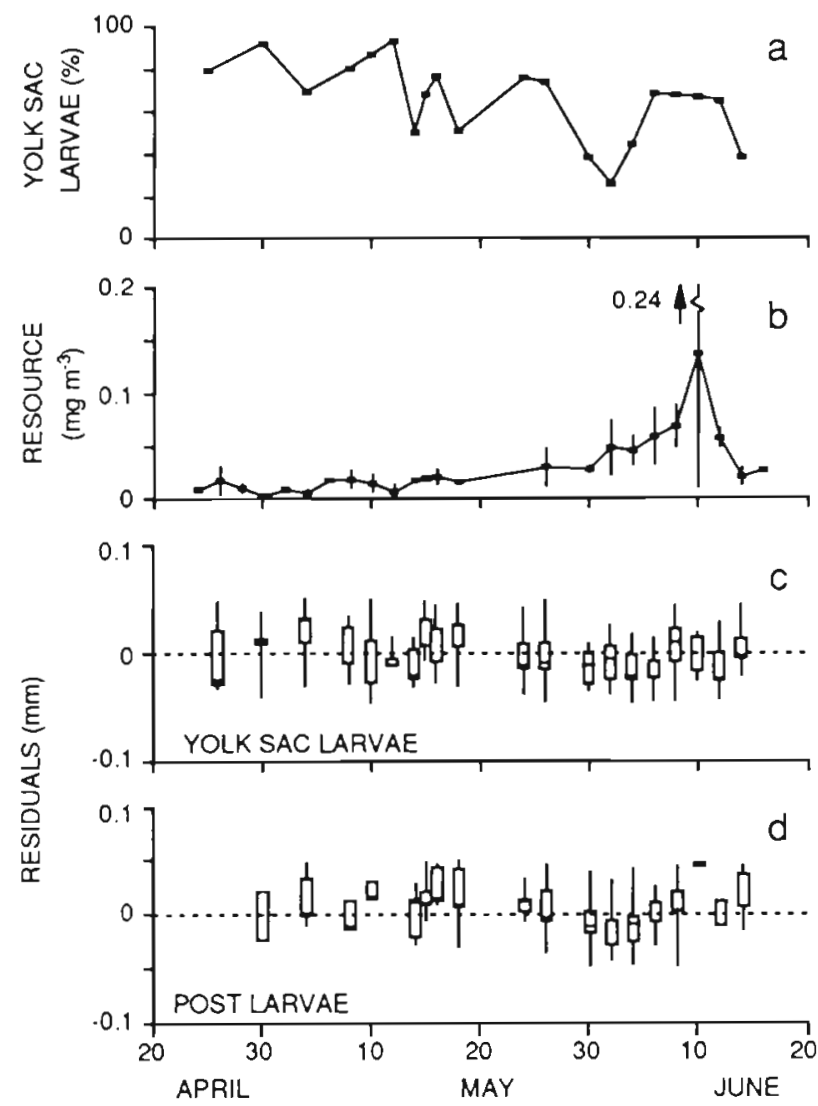

Fig. 7. Ammodytes sp. Seasonal variations in (a) the percentage of sand lance larvae with yolk reserves, (b) the food resource available to the larvae, and the relative physiological condition at date for (c) yolk-sac larvae and (d) postlarvae. The residuals of the regression between body height and standard length were used as an index of relative condition (see 'Materials and Methods'). In (c) and (d), the central box covers the middle $50 \%$ of the condition values (interval between first and third quartiles) for a given day, the vertical lines cover the range (minimum to maximum value) and the horizontal bar in the box represents the median

assume that first feeding must start around the same date each year. On the other hand, the phytoplankton bloom, which triggers the main reproduction effort of copepods and the massive production of larval fish prey, is subordinate to the break-up of the ice cover which allows the penetration of light at depth. The date of ice break-up is determined by meteorological for-
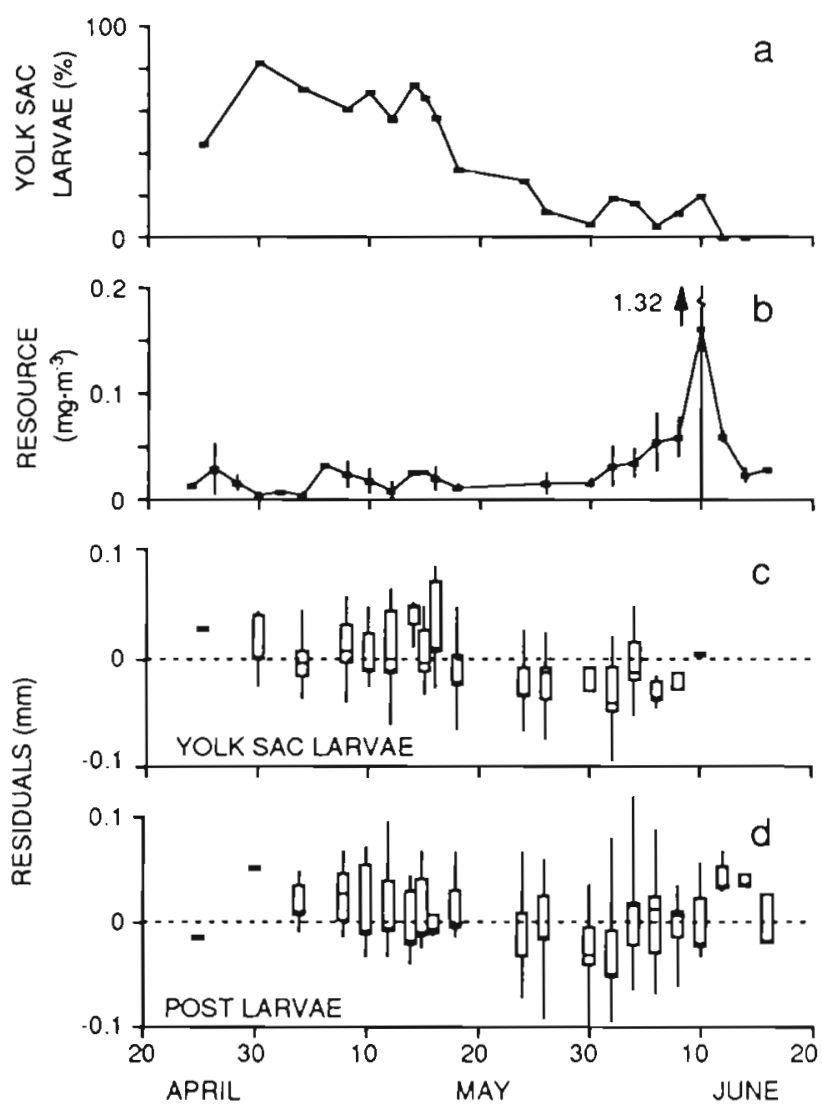

Fig. 8. Boreogadus saida. Seasonal variations in (a) the percentage of Arctic cod larvae with yolk reserves, (b) the food resource available to the larvae, and the relative physiological condition at date for (c) yolk-sac larvae and (d) postlarvae. The residuals of the regression between body height and standard length were used as an index of relative condition (see 'Materials and Methods'). Box and whisker plots in (c) and (d) as in Fig. 7

cing and can vary by several weeks from year to year (Hamilton 1985, Lepage \& Ingram 1991).

Contrary to the case for benthic invertebrates which synchronize the release of gametes with the primary production cycle (see Starr et al. 1990 for a review), there is little indication that fish can adjust their spawning period to compensate for interannual variations in the timing of the production of their prey (Cushing 1969). Yearly variations in the timing of the ice break- 

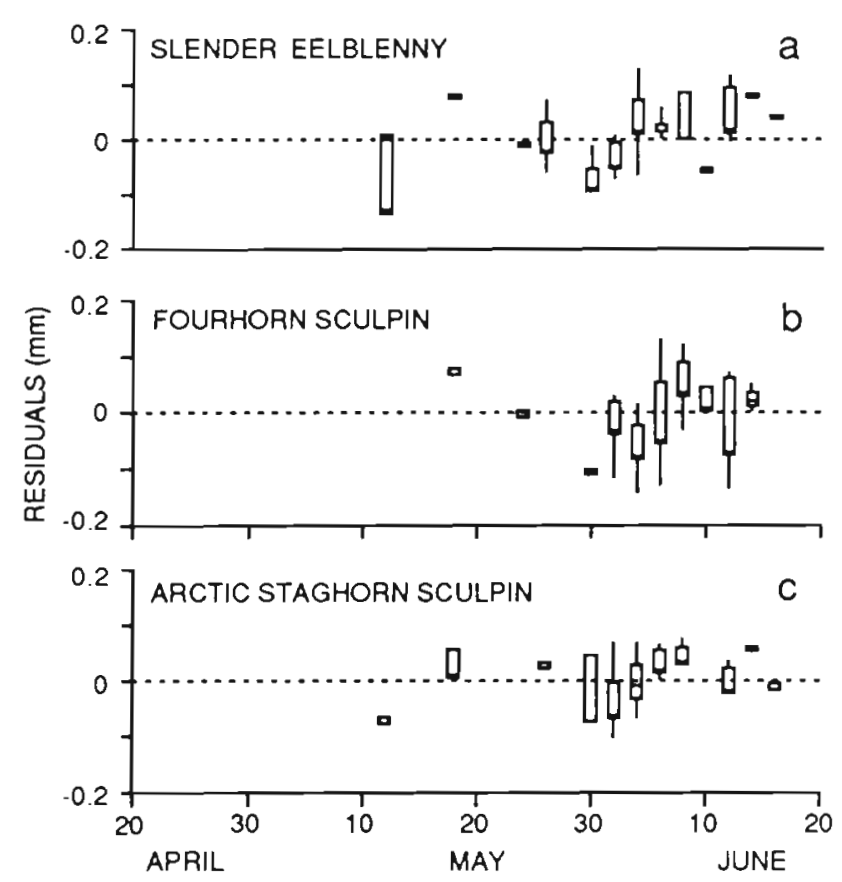

Fig. 9. Seasonal variations in the average physiological condition of the larvae of Stichaeidae and Cottidae (residual of the regression between body height and standard length). Box and whisker plots as in Fig. 7.

up and the phytoplankton bloom, in relation to a static spawning period and a constant developmental rate under the ice, could generate recruitment variability in species such as sand lance and Arctic cod which occur before the ice break-up.

\section{Reproduction strategies of fish in ice-covered Hudson Bay}

Two distinct reproduction strategies were observed among the several marine species spawning in southeastern Hudson Bay. The first strategy was exemplified by opportunistic species (or $r$-selected, sensu Pianka 1970) such as sand lance and Arctic cod, which produced large numbers of small larvae. These emerged before the ice break-up, fed with more or less efficiency on relatively small prey, and apparently experienced a critical period of starvation at yolk resorption. Because of the unavoidable trade-off between number and size of offspring, the newly-hatched larvae of sand lance and Arctic cod were characterized by relatively poor foraging abilities and appeared intrinsically prone to a critical period of starvation. Our results suggest that the timing of reproduction in these species is adapted to match this ineluctable critical period with maximum food availability in order to minimize starvation mortality. This adaptation should be most evident in $r$ strategists of temperate or high-latitude ecosystems where production is discontinuous and limited to a short period during the year (Cushing 1975). In 1988, the match appeared reasonably good for sand lance but perhaps less so for Arctic cod. Whether interannual variations in this synchronism cause variations in the recruitment of pelagic species in Hudson Bay ithe critical period and match/mismatch hypotheses) remains conjectural. However, Ellersten et al. (1989) showed that year-class strength in Arcto-Norwegian cod Gadus morhua was related to environmental temperature which controls the match or mismatch between firstfeeding larvae and the production of Calanus finmarchicus nauplii, their primary prey.

The second reproduction strategy was exemplified by coastal families such as Stichaeidae and Cottidae which produced few but large and competent larvae that emerged after the break-up when not only prey but also light to detect prey were available (Gilbert 1991). These larvae fed efficiently on relatively large prey even before yolk resorption (see also Lyczkowski Laroche 1982). There was no evidence of a critical period at yolk-sac resorption. Large and efficient larvae such as those of Stichaeidae and Cottidae are unlikely to be vulnerable to starvation (McGurk 1986, Duarte \& Alcaraz 1989) and should be less affected by variations in the timing of the phytoplankton bloom.

Acknowledgements. This study was part of a collaborative program between GIROQ and the Department of Fisheries and Oceans Canada (Institut Maurice-Lamontagne). Field and laboratory work was funded by grants to L.F. from NSERC and DFO, and by grants to GIROQ from NSERC and the Fonds FCAR of Québec. R.D. and M.G. were supported by scholarships from the Department of Indian and Northern Affairs. Helicopter time was provided by DFO. The Centre d'études nordiques (Université Laval) provided accommodation at its field station in Kuujjuarapik where we benefited from the assistance of the superintendent $C$. Côté. Special thanks to C. Dutil for her contribution to this study. G. Bergeron, M. Frenette, N. Hamel, L. Michaud, M.-A. Rémillard and S. Tourangeau helped in the field or the laboratory. L. Legendre (GIROQ) and J.-C. Therriault (DFO-IML) kindly supplied the chlorophyll data. Two anonymous referees critically reviewed the manuscript.

\section{LITERATURE CITED}

Anderson, J. T (1988). A review of size dependent survival during pre-recruit stages of fishes in relation to recruitment. J. Northw. Atlant. Fish. Sci. 8: 55-66

Bailey, K. M. (1984). Comparison of laboratory rates of predation on five species of marine fish larvae by three planktonic invertebrates: effects of larval size on vulnerability Mar. Biol. 79: 303-309

Bailey, K. M., Yen, J. (1983). Predation by a carnivorous marine copepod, Euchaeta elongata Esterly, on eggs and larvae of Pacific hake, Merluccius productus. J. Plankton Res. 5: 71-82

Bolduc, M. (1990). Distribution spatiale de la condition phy- 
siologique des stades postlarvaires de capelan Mallotus villosus en fonction de l'abondance de leur ressource. M.Sc thesis, Laval University

Buckley, L. J., Lough, R. G. (1987). Recent growth, biochemical composition, and prey field of larval haddock (Melanogrammus aeglefinus) and Atlantic cod (Gadus morhua) on Georges Bank. Can. J. Fish. Aquat. Sci. 44: 14-25

Cushing, D. H. (1969). The regularity of the spawning season of some fishes. J. Cons. int. Explor. Mer 33: 81-92

Cushing, D. H. (1974). The possible density-dependence of larval mortality and adult mortality in fishes. In: Blaxter. J. H. S. (ed.) The early life history of fish. Springer-Verlag, New York, p. 103-112

Cushing, D. H. (1975). Marine ecology and fisheries. Cambridge University Press, New York

Dahlberg, M. D. (1979). A review of survival rates of fish eggs and larvae in relation to impact assessments. Mar. Fish. Rev. 41: 1-12

Duarte, C. M., Alcaraz, M. (1989). To produce many small or few large eggs: a size-independent reproductive tactic of fish. Oecologia 80: 401-404

Ehrlich, K. F., Blaxter, J. H. S., Pemberton, R. (1976). Morphological and histological changes during growth and starvation of herring and plaice larvae. Mar. Biol. 35: $105-118$

Ellersten, B., Fossum, P., Solemdal, P., Sundby, S. (1989). Relation between temperature and survival of eggs and first-feeding larvae of northeast Arctic cod (Gadus morhua L.). Rapp. P.-v. Réun. Cons. int. Explor. Mer 191: 209-219

Fortier, L., Harris, R. P. (1989). Optimal foraging and densitydependent competition in marine fish larvae. Mar. Ecol. Prog. Ser. 51: 19-33

Fortier, L., Leggett, W. C. (1985). A drift study of larval fish survival. Mar Ecol. Prog. Ser. 25: 245-257.

Gilbert, M. (1991). Distribution et nutrition des stades larvaires de poissons du sud-est de la baie d'Hudson: influence du couvert de glace sur la disponibilité de la lumière et des proies. M.Sc. thesis, Laval University

Gosselin, M., Legendre, L., Demers, S., Ingram, R. G. (1985). Responses of sea-ice microalgae to climatic and fortnightly tidal energy inputs (Manitounuk Sound, Hudson Bay). Can. J. Fish. Aquat. Sci. 42: 999-1006

Grainger, E. H. (1988). The influence of a river plume on the sea-ice meiofauna in south-eastern Hudson Bay. Estuar. coast. Shelf Sci. 27: 131-141

Grover, J. J., Olla, B. L. (1986). Morphological evidence for starvation and prey size selection of sea-caught larval sablefish, Anoplopoma fimbria. Fish. Bull. U.S. 84: $484-489$

Håkanson, J. L. (1989). Condition of larval anchovy (Engraulis mordax) in the Southern California Bight, as measured through lipid analysis. Mar. Biol. 102: 153-159

Hamilton, K. (1985). Evidence for tropical-midlatitude teleconnections in the eighteenth and nineteenth centuries. Trop. Ocean-Atmos. Newsl. 30

Hjort, J. (1914). Fluctuations in the great fisheries of northern Europe viewed in light of biological research. Rapp. P.-v. Réun. Cons. perm. int. Explor. Mer 20: 1-228

Hunter, J. R. (1976). Report of a colloquium on larval fish mortality studies and their relation to fishery research. January 1975. NOAA Tech. Rept. NMFS CIRC-395, 6 p.

Ingram, R. G. (1981). Characteristics of the Great Whale River plume. J. geophys. Res. 86(C): 2017-2023

Ingram, R. G., Larouche, P. (1987). Variability of an under-ice river plume in Hudson Bay. J. geophys. Res. 92(C): 9541-9547

Jennings, S. (1991). The effects of capture, net retention and preservation upon lengths of larval and juvenile bass Dicentrarchus Jabrax (L.). J. Fish. Biol. 38: 349-357

Kiorbøe, T., Munk, P., Richardson, K., Christensen, V., Paulsen, H. (1988). Plankton dynamics and larval herring growth, drift and survival in a frontal area. Mar. Ecol. Prog. Ser. 44: 205-219

Koslow, J. A., Brault, S., Dugas, J., Fournier, R. O., Hughes, P. (1985). Condition of larval cod (Gadus morhua) off southwest Nova Scotia in 1983 in relation to plankton abundance and temperature. Mar Biol. 86: 113-121

Kruse, G. H., Dalley, E. L. (1990). Length changes in capelin, Mallotus villosus (Müller), larvae due to preservation in formalin and anhydrous alcohol. J. Fish. Biol. 36: 619-621

Legendre, L., Ingram, R. G., Poulin, M. (1981). Physical control of phytoplankton production under sea ice (Manitounuk Sound, Hudson Bay). Can. J. Fish. Aquat. Sci. 38 1385-1392

Leggett, W. C. (1986). The dependence of fish larval survival on food and predator densities. In: Skreslet, S. (ed.) The role of freshwater outflow in coastal marine ecosystems. NATO ASI Series Vol. G7. Springer-Verlag, Berlin, p. 117-137

Leiby, M. M. (1984). Life history and ecology of pelagic fish eggs and larvae. In: Steidinger, K. A., Walker, L. M. (eds.) Marine plankton life cycle strategies. CRC Press, Boca Raton, p. 121-140

Lepage, S., Ingram, R. G. (1991). Variation of upper layer dynamics during breakup of the seasonal ice cover in Hudson Bay. J. geophys. Res. 96: 12711-12724

Lyczkowski Laroche, J. (1982). Trophic patterns among larvae of five species of sculpins (family: Cattidae) in a Maine estuary. Fish. Bull. U.S. 80: 827-840

Marr, J. C. (1956). The 'critical period' in the early life history of marine fishes. J. Cons. int. Explor. Mer 21: 160-170

May, R. C. (1974). Larval mortality in marine fishes and the critical period concept. In: Blaxter, J. H. S. (ed.) The early life history of fish. Springer-Verlag, New York, p. 3-19

McGurk, M. D. (1986). Natural mortality of marine pelagic fish eggs and larvae: role of spatial patchiness. Mar. Ecol. Prog. Ser. 34: 227-242

Monteleone, D. M., Peterson, W T. (1986). Feeding ecology of American sand lance Ammodytes americanus larvae from Long Island Sound. Mar. Ecol. Prog. Ser. 30: 133-143

Nakai, Z., Kosaka, M., Ogura, M., Hayashida, G., Shimozono, H. (1969). Feeding habit, and depth of body and diameter of digestive tract of shirasu, in relation with nutritious condition. J. Coll. Mar. Sci. Technol., Tokai Univ. 3: 23-34 (in Japanese, English abstract)

Nakata, K. (1988). Alimentary tract contents and feeding conditions of ocean-caught post larval Japanese sardine, Sardinops melanostictus. Bull. Tokai Reg. Fish. Res. Lab. 126: $11-23$

Nielson, J. D., Perry, R. I., Valerio, P., Waiwood, K. G. (1986). Condition of Atlantic cod Gadus morhua larvae after the transition to exogenous feeding: morphometrics, buoyancy and predator avoidance. Mar. Ecol. Prog. Ser. 32: 229-235

O'Connell, C. P. (1980). Percent of starving northern anchovy (Engraulis mordax) in the sea as estimated by histological methods. Fish. Bull. U.S. 78: 475-489

Parsons, T. R., Maita, Y., Lalli, C. M. (1984). A manual of chemical and biological methods for seawater analysis. Pergamon Press, New York

Pianka, E. R. (1970). On r- and K-selection. Am. Nat. 104: 592-597

Ponomarenko, V P. (1967). The feeding of the larvae and fry of the Arctic cod (Boreogadus saida Lepechin) in the Barents and Kara seas. Polyarn. Nauchno-Issled. Praektnyi Inst. Morsk. Rybn. Khoz. Okeanogr., Materialy Rybokhoz. 
Issled. Severnago Basseina. 10: 20-27 (Transl. from Russian by U.S. Bur Sport Fish. Wildl., 1968)

Purcell, J. E., Siferd, T. D., Marliave, J. B. (1987). Vulnerability of larval herring (Clupea harengus pallasi) to capture by the jellyfish Aequorea victoria. Mar. Biol. 94: 157-162

Runge, J. A., Ingram, R. G. (1988). Underice grazing by planktonic, calanoid copepods in relation to a bloom of ice microalgae in southeastern Hudson Bay. Limnol. Oceanogr. 33: 282-288

Runge, J. A., Ingram, R. G. (1991). Under-ice feeding and diel migration by the planktonic copepods Calanus glacialis and Pseudocalanus minutus in relation to the ice algal production cycle in southeastern Hudson Bay, Canada. Mar. Biol. 108: 217-225

Runge, J. A., Therriault, J.-C., Legendre, L., Ingram, R. G. Demers, S. (in press). Coupling between ice microalgal productivity and the pelagic food web in southeastern Hudson Bay. Polar. Res.

Setzler-Hamilton, E. M., Wright, D. A., Martin, F. D., Millsaps, C. V., Whitlow, S. I. (1987). Analysis of nutritional condition and its use in predicting striped bass recruitment: field studies. Am. Fish. Soc. Symp. 2: 115-128

Shelbourne, J. E. (1957). The feeding and condition of plaice larvae in good and bad plankton patches. J. mar. biol. Ass U.K. 36: 539-552

Shepherd, J. G., Cushing, D. H. (1980). A mechanism for density dependent survival of larval fish as the basis of a stock-recruitment relationship. J. Cons. int. Explor. Mer 39: $160-167$

This article was submitted to the editor
Starr, M., Himmelman, J. H., Therriault, J.-C. (1990). Direct coupling of marine invertebrate spawning with phytoplankton blooms. Science 247: 1071-1074

Theilacker, G. H. (1986). Starvation-induced mortality of young sea-caught jack mackerel. Trachurus symmetricus, determined with histological and morphological methods. Fish. Bull. U.S. 84: 1-17

Tourangeau, S., Runge, J. A. (1991). Reproduction of Calanus glacialis in relation to an ice microalgal bloom in southeastern Hudson Bay. Mar Biol. 108: 227-233

Tremblay, C., Runge, J. A., Legendre, L. (1989). Grazing and sedimentation of ice algae during and immediately after a bloom at the ice-water interface. Mar. Ecol. Prog. Ser. 56: 291-300

Ware, D. M. (1975). Relation between egg size, growth, and natural mortality of larval fish. J. Fish. Res. Bd Can. 32: 2503-2512

Westernhagen, $H$. von, Rosenthal, H. (1981). On condition factor measurements in Pacific herring larvae. Helgoländer Meeresunters. 34: 257-262

Wyatt, T. (1972). Some effects of food density on the growth and behaviour of plaice larvae. Mar. Biol. 14: 210-216

Yin, M. C., Blaxter, J H. S. (1986). Morphological changes during growth and starvation of larval cod (Gadus morhua L.) and flounder (Platichthys flesus L.). J. exp. mar. Biol. Ecol. 104: 215-228

Yin, M. C., Blaxter, J. H. S. (1987). Feeding ability and survival during starvation of marine fish larvae reared in the laboratory. J. exp. mar. Biol. Ecol. 105: 73-83

Manuscript first received: June 11, 1991

Revised version accepted: September 4, 1991 